\title{
A water-piracy hypothesis for the stagnation of Ice Stream C, Antarctica
}

\author{
R. B. Alley, S. ANandakrishyan, \\ Earth System Science Center and Department of Geosciences, The Pennsyliania State University, University Park, PA 16802, U.S.A. \\ C. R. BENTLEY AND N. LORD \\ Geophysical and Polar Research Center, Lnizersity of Wisconsin-Madison, Madison, WI 53706, U.S.A.
}

\begin{abstract}
Water piracy by Icc Stream B, West Antarctica, may have causcd neighboring Ice Strcam C to stop. The modern hydrologic potentials near the upstrcam end of the main trunk of Ice Stream $C$ are directing water from the $C_{\text {. }}$ catchment into Ice Stream B. Interruption of water supply from the catchment would have reduced water lubrication on bedrock regions projecting through lubricating basal till and stopped the ice stream in a few years or decades, short enough to appear almost instantancous. This hypothesis explains several new data sets from Ice Stream C and makes predictions that might be testable.
\end{abstract}

\section{INTRODUCTION}

The stability of the West Antarctic ice sheet is related to the behavior of the fast-moving ice streams that drain it. Much effort thus has been directed towards understanding these ice streams. The United States program has cspecially focuscd on those ice streams $(\Lambda-E)$ flowing across the Siple Coast into the Ross Ice Shelf. Among the most surprising discoveries on the Siple Coast icc streams has becn how rapidly they are changing now and have changed recently (see review by Alley and Whillans (1991).

Many areas have been examined in dctail, and most show non-steady behavior, including large changes in ice velocity and grounding-line position over historical pcriods (Stephenson and Bindschadler, 1988; Thomas and others, 1988; Bindschadler, 1993) and modern rates of thickness change approaching or cxcceding 1 myear $^{1}$ in screral areas (MacAyeal and others, 1987, 1989; Shabtaie and others, 1988; Whillans and Bindschadler, 1988; Bindschadler and othcrs, 1989, 1993). Probably the most dramatic change is that Ice Stream C apparently stagnated about a century ago (Rose, 1979; Shabtaic and others, 1987; Retzlaff and Bentley, 1993); it has the radar signature of an active ice stream, but the crevasses of its shear margins and within the ice stream itself are buried by about a century of snowfall.

By analogy to its neighbors, Ice Stream C probably was moving several hundred meters per year. No data are available on how long it took to slow down, but it dropped beneath the speed threshold necded to kecp marginal crevasses open almost synchronously (within about 30 years) along about $300 \mathrm{~km}$ of the ice stream extending up-glacier from the grounding line (Retzlaff and Bentley, 1993).

Such a dramatic change in ice-stream bchavior poses a large challenge to glaciological research. In seeking to understand it, we may learn much about the behavior of ice streams.

\section{PREVIOUS HYPOTHESES}

The behavior of Ice Stream $C$ has provoked much speculation. Rose (1979) suggested that it is a surging ice stream, which cycles between fast and slow flow in the same way as some mountain glaciers do. This simple analogy is unlikely because most surging glaciers spend most of their time in the slow mode, but four of the five main Siple Coast ice streams are moving rapidly. Attempts to model surges in Antarctic ice streams failed to produce them (Radok and others, 1987). Surging in mountain glaciers sccms to require build-up of ice in a reservoir area, and surge termination follows draw-down of the reservoir, but the ice reservoir (catchment) of Ice Stream $\mathrm{C}$ is not strongly drawn down and looks like those of the other Siple Coast ice streams. Surging thus seems unlikely and we discount this hypothesis. However, some of the mechanisms that have been associated with surging might remain viable under different guises and below we discuss one (switches between channelized and distributed subglacial water drainages).

In discussing surging and changes in catchment areas, Rose (1979) also indirectly suggested the possibility of piracy - perhaps Ice Stream B had beheaded Ice Stream $\mathrm{C}$ by stealing ice from its catchment area. However, careful mapping (Shabtaie and others, 1988; Retzlaff and others, 1993) shows that this has not happened, although continuation of ongoing trends in thickness change might cause it to happen in the future.

In his discussion of Rose's (1979) paper and in 
Thomas and others (1988), Thomas suggested that recent grounding near the mouth of Ice Stream C might have created an ice plain or ice rises that generated backpressure and stopped the ice stream. By analogy to Ice Stream B, this grounding might have been caused by rapid scdimentation at the grounding line, possibly supplied by a deforming subglacial till (Alley and others, 1987a). However, we consider it unlikely that this would stop the ice stream, primarily because of analogy to Ice Stream B. There, an extensive ice plain leads to the Crary Icc Rise complex. Crary Ice Rise has a large restraining effect on ice flow (MacAyeal and others, 1987, 1989), yet Ice Stream B curves around it and flows vigorously. On the ice plain, some strain rates are actually extensional along flow (Bindschadler and others, 1987) and not compressional as would be expected if backpressure were braking the ice stream. Most of the strain rates do show compression along flow (Bindschadler and others, 1987), but this can be explained by the transverse extension caused by down-glacier widening of the ice stream without appealing to ice-plain back-pressure; Bindschadler and others (1987) neglected gradients in longitudinal deviatoric stresses in their assessment of the force balance of the icc plain of Ice Stream B.

Retzlaff and Bentley (1993) suggested that instability of a distributed subglacial water system may have led to channelization of the water and reduced basal lubrication, stopping the ice stream. Water apparently flows beneath Ice Stream B in a high-pressure distributed systcm, which can be modeled as a thin film, and the high water pressures allow rapid bed deformation or sliding (Alley and others, 1987b; Allcy, 1989b; Kamb, 1991; Kamb and Engelhardt, 1991). Walder (1982) showed that, if such a distributcd water system bccomes thicker than a few millimeters, perturbations in its thickness will tend to grow. A film system thus might collapse into a low-pressure channclized system. Channel formation would be most likely near the grounding line, where the water supply is largest. Once formed, channels might grow headward. We know of no accurate estimates of possible rates of headward growth of channels into a distributed water system, or even whether such growth could occur. (The Walder analysis is two-dimensional and does not consider variations along flow.) However, if up-glacicr growth rates occurred at rates similar to downglacier flow rates of water, just a few years or decades would be needed for channels to extend the length of the ice strcam (see below).

Kamb and others (1985) and Kamb (1987) discussed the collapse within hours of a distributed, linked-cavity drainage system to a channelized one beneath Variegated Glacier, Alaska, which caused termination of a surge of the glacicr. However, this behavior may not tell us much about Ice Stream C. Variegated Glacier normally has a channelized drainage system maintained by abundant surface meltwater reaching the bed through moulins. Disruption of this surface-fed, channelized system triggered the surge, and re-establishment of this channelized system terminated the surge in a wave that propagated down-glacier. Theory suggests the possibility of qualitatively different behavior of subglacial water with point versus distributed sources (e.g. Weertman, 1972). Because Ice Stream G lacks delivery of abundant surface melt to the bed at certain points, there is no reason to expect the basal system of Ice Stream $G$ to change in the same way as observed beneath Variegated Glacier at the end of its surge.

Arguments have been advanced against the possibility of film-to-channel collapse beneath an ice stream (Alley, $1989 \mathrm{a}$ ). The Walder instability requires a film of more than a few millimeters thickness. Calculations for the likely film thickness at the down-glacier end of Ice Stream $C$, following Alley and others (1987b) and including likely uncertainties in the basal shear stress and the geothermal flux, include within the error limits films thick enough to be unstable and thin enough to be stable. Weertman and Birchfield (1983) argued that, although the perturbation analysis of Walder (1982) was correct, development of the infinitesimal perturbations to finite size would induce other changes that would prevent maintenance of steady-state channels. This question is not fully solved.

Perhaps more importantly, the Walder analysis assumed a rigid bed. Soft sediments could creep into and close an incipient channel, as they have been observed to creep into subglacial tunnels (Boulton, 1976; Boulton and Hindmarsh, 1987). An incipient channel would have small sediment-transport capacity, and so would be closed rapidly, preventing growth to a low-pressure, steady-state configuration (Alley, 1989a). Walder and Fowler (1994) showed that any channels that do form over a soft bed will have relatively high water pressure owing to the effects of the soft sediment, allowing continuation of some basal lubrication.

We recognize that the Weertman and Birchfield (1983) and Alley (1989a) arguments are based on theory and that theory can err. We thus maintain the film-tochannel collapse of Retzlaff and Bentley (1993) as a working hypothesis.

A thick, rapidly deforming glacier bed allows much debris transport and thus requires a large debris source. Unconsolidated or poorly consolidated sediments are the most likely source. Boulton and Jones (1979) pointed out that long-term action of ice would remove such sediments. This would cause the deforming-till layer to thin, which might slow or stop the ice stream. Anandakrishnan and Bentley (1994) have reported that low scismic-velocity (hence poorly consolidated and easily eroded) sediments exist beneath the till of Ice Stream $C_{\text {, }}$, with thickness varying from $400 \mathrm{~m}$ at onc sitc to only $100 \mathrm{~m}$ nearby. Such large variations suggest the possibility of these sediments pinching out elsewhere. Because a till layer of variable thickness does seem to exist widely bencath Ice Stream C (Atre and Bentley, 1990, 1993), full loss of the sediments supplying that till layer cannot have occurred. However, sediment loss by erosion could have caused till thinning, which in turn could have caused the growth of sticky spots of thin or zero till that slowed the ice strcam (Alley, 1993). Such sticky spots figure prominently in our water-piracy hypothesis.

The possibility of water piracy by Ice Stream B combines elements of Rose's ice piracy and Retzlaff and Bentley's film-to-channel collapse. We began considering the water-piracy idea in group meetings at the University of $W$ isconsin during the mid-1980s and it has influenced our field and theoretical studies since then. It has been 


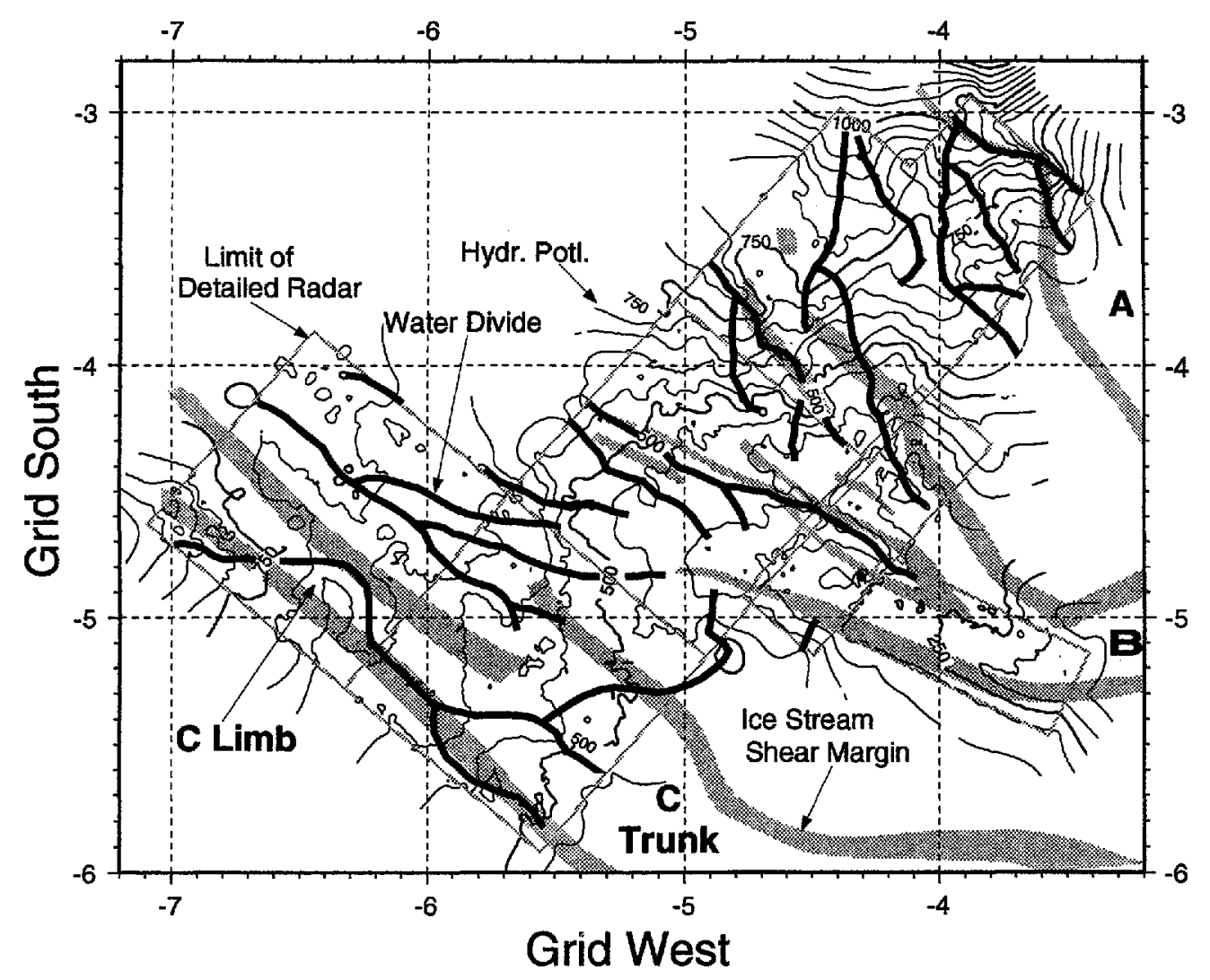

Fig. 1. Hydrologic potential map of the up-glacier parts of Ice Streams B and C. Polential is calculated as ice-surface elevation minus $0.1 \times$ bed elevation in $m$ (Paterson, 1981, p.142), and is equivalent to a head in units of ice thickness; multiply all values by $\rho_{\mathrm{i}} g \approx 9000$, where $\rho_{\mathrm{i}}$ is the ice density, to obtain the potential in units of Pa. One degree on the grid scale is $111 \mathrm{~km}$. Water-flow divides are indicated by heavy lines, and show water flowe from the limb of Ice Stream C to Ice Stream $B$.

presented briefly by Alley and Whillans (1991). We now believe that enough data and interpretations are available to justify presentation to the community in greater detail.

\section{CRITICAL OBSERVATIONS}

Interpretations of several new data sets are critical to our hypothesis. We summarize these briefly here. We find it useful to distinguish between the wide, main, downglacier part of the ice stream, which we call the trunk, and the narrow up-glacier extension, which we call the limb (Fig. 1).

The ice-stream trunk stopped almost synchronously (Retzlaff and Bentley, 1993). Ice-flow velocities on the trunk of Ice Stream $\mathrm{C}$ arc barely more than measurement error (Whillans and others, 1987), although slow basal motion continues (Anandakrishnan and Bentley, 1993). The ice stream is delineated on radar records by the marginal crevassing typical of active ice streams, but the crevasses are bridged by many meters of snow accumulation. Short-pulse radar measurements of snow-bridge thicknesses combined with accumulation-ratc measurements show that the trunk stopped nearly synchronously ( \pm 30 years) about 130 years ago. A profile crossing the up-glacier end of the trunk and the down-glacier end of the limb shows a slightly more recent shut-down, but the difference is not statistically significant.
The limb of Ice Stream $C$ extending up-glacier may still be active. A short-pulsc radar profile across the limb well up-glacier shows a significantly more recent stagnation than for the trunk (Rctzlaff and Bentley, 1993). Near the truc-north side of the limb, open crevasses have been observed from aircraft, indicating active ice flow (Retzlaff and Bentley, 1990, 1993). Active ice flow with many crevasses bridged might occur; balance velocities (and by analogy, whatever velocities apply to the current conditions) for the limb are slower than for the main part of an active ice stream, so the limb should shear past its margins and open its marginal crevasses more slowly than typical for active ice streams, allowing a greater chance of bridging those crevasses. No ice-flow vclocities have been measured in the limb but, just beside it toward Ice Stream B, Whillans and Van der Veen (1993) observed a velocity transitional between values typical of inlandice and ice-stream flow, consistent with transitional flow there from inland to ice stream.

The bed of the trunk is well lubricated in most places, although with local sticky spots supporting most of the basal shear stress. Micro-earthquake monitoring near Upstream C camp on the trunk (Anandakrishnan and Bentlcy, 1993) shows that brittle fracture is much more common beneath Ice Stream $\mathrm{C}$ than beneath Ice Stream B. Quakes are generated along small thrust faults at or near, and parallel to, the ice-stream bed, with slip in the direction of local ice flow. The rupture surfaces are 
on the order of $10 \mathrm{~m}$ across. Stress drops in the quakes are typically on the order of 1 bar $\left(10^{5} \mathrm{~Pa}\right)$ and a quake preferentially sets off others within $400 \pm 400 \mathrm{~m}$ but cxtending as far as $1.5 \mathrm{~km}$ (Anandakrishnan and Bentley, 1993; Anandakrishnan and Alley, 1994).

Stress drops in ordinary earthquakes are not expected to relieve all of the applied stress. Earlier workers (e.g. Wyss and Brune, 1968; Brune, 1970) suggested that perhaps $1-10 \%$ of the applied stress is relieved in a quake. Newer estimates are scarce, possibly because of the difficulty of estimating the applied stress. If simple analogy holds and these old estimates are approximately accurate, the microearthquakes under Ice Strcam C occur on failure planes in sticky-spot regions supporting 100-1000 times more basal shear stress than the regional average of about 0.1 bar (Anandakrishnan and Alley, 1994). In most earthquakes, aftershocks are generated in a region of similar linear dimension to the length of the rupture surface (Das, 1992; in a single case, aftershocks have been documented to a distance of 17 times the source size; Hill and others, 1993). Again, if simple analogy holds, the observation of aftershocks within hundreds of meters of a quake suggests a rupture surface of hundreds of meters, compared to an estimate of $10 \mathrm{~m}$ from the corner frequency of the energy spectrum of the quakes (Anandakrishnan and Bentley, 1993; Anandakrishnan and Alley, 1994).

The simplest interpretation of these data is that regions between sticky spots are very well lubricated, so that stress is transmitted up to $1.5 \mathrm{~km}$ for rupture of a locked region spanning $10 \mathrm{~m}$. A 10 bar stress on $10 \mathrm{~m}$ long sticky spots between perfectly lubricated areas under an average basal shear stress of 0.1 bar would imply $100 \mathrm{~m}$ spacing of the sticky spots. Non-zero strength of the lubricated areas would increase the spacing we estimate. In comparison, the clustering of micro-earthquakes suggests a few hundred meters spacing (Anandakrishnan and Alley, 1994), reasonably good agreement given the order-of-magnitude nature of these calculations.

These data suggest that in most places the ice stream is well lubricated and supports littlc or no basal shear stress; localized sticky spots support most of the stress (Anandakrishnan and Alley, 1994). This would concentrate the stress sufficiently to allow brittle fracture and would allow stress changes associated with a micro-earthquake to be transmitted long distances to other sticky spots. The scarcity of seismicity beneath Ice Stream B suggests that any sticky spots therc arc bettcr lubricated than those beneath Ice Stream C (Anandakrishnan and Bentley, 1993).

Active-scismic data, and more recently drilling, have shown that Ice Stream B is underlain by a meters thick, very soft till that probably deforms and lubricates basal motion (Blankenship and others, 1987; Kamb and Engelhardt, 1991). Theoretical estimates of its strength (Alley and others, 1987b) and laboratory (Kamb, 1991; Kamb and Engelhardt, 1991) and smallscale in-situ strength tests (personal communication from H. Engelhardt and B. Kamb) prcclude basal models in which much of the bed supports a significant shear stress without deforming rapidly.
The original interpretations of the basal properties of Ice Stream B were based on seismic-velocity analysis and on seismic profiling (Blankenship and others, 1987; Rooney and others, 1987). No velocity analyses have been conducted on Ice Stream G, but profiling Atre and Bentley, 1993) reveals a layer apparently similar to that beneath Ice Strcam B. Seismic-phase analysis shows that extensive parts of this layer have low seismic vclocity similar to values beneath Ice Suream B. Thus, it is likely that a soft, deformable till cxists beneath Ice Stream C. Phase analysis also suggests spatial variability in the properties of the uppermost part of the till but cannot reveal how large the variations are (Atre and Bentley, 1990, 1993).

Imagery of the ice stream shows an "island" of ice in its center that looks more mottled than its surroundings, and the flowlines in the surroundings seem to be deflected around that island Jacobel and others, 1993). Radar data show that the island coincides with a bedrock high (Jacobel and others, 1993). High spatial variability in imagery, probably linked to bedrock highs, is known to occur over regions of enhanced basal drag (sticky spots) on Ice Stream E (MacAyeal, 1992), which strengthens the possibility that localized sticky spots exist beneath Ice Stream C.

Water piracy has accurred from the catchment area of Ice Stream $C$ to the trunk of Ice Stream B. Rose (1979) and Shabtaie and Bentley (1988) noted the combination of steep bedrock topography under flat surface topography, suggesting important dynamic effects. In particular, subglacial water flow is controlled by the ice-surface slope and about 10 times less importantly by the bed slope (e.g. Paterson, 1981, chapter 8, equation 14). In all regions of stcep ice-surface slope, ice and water flow are nearly parallel and down the gradicnt in ice-surface elevation. But, in regions of steep bed slope and gentle surface slope, water flow may occur down the bed-elevation gradient or between it and the icc-surface gradient, whereas ice flow will continue along the ice-surface gradient.

Figure 1 shows hydrologic-potential data and drainage divides for subglacial water, assuming that the hydrologic potential is controlled by surface and bed clcvations for constant-density ice, and not by gradients in basal shear stress (sec below). Surface and bed elevations are from Retzlaff and others (1993). It appcars that water generated by basal melting in the catchment of Ice Stream C and along the limb is bcing divertcd to Ice Strcam B, near where the limb meets the trunk of Ice Stream C. Despite the tight flight-line spacing (5 or $10 \mathrm{~km}$ grid) and high accuracy $\pm 7 \mathrm{~m}$ for the surface and $\pm 40 \mathrm{~m}$ for the bed) of the data, there is some ambiguity in drawing the drainage divides. This uncertainty increases if we try to apply the data to 130 years ago, because surface elevations may have changed in the interim. But, the appearance of modern watcr piracy is strong and the possibility that this has existed for some time must be considercd.

The lubricant for active ice streams is spatially zariable. The evidence for large spatial variation in basal drag of 
active ice streams is becoming strong (see review by Alley (1993)). Seismic studies beneath Ice Stream B showed lubricating till thinning to below the seismic resolution of $1-2 \mathrm{~m}$ in localized areas, which suggested the possibility of till discontinuity (Rooney and others, 1987). If a localized region has a high basal shear stress bccause of thin or absent till, the water pressure in a distributed system will be reduced in that region and water flow will occur preferentially toward it, partially lubricating it (Weertman, 1972; Alley, 1993). The ice stream thus may have water-lubricated sticky regions surrounded by till-lubricated slippery regions. The water lubrication will allow much faster motion for a given shear stress than would occur in the absence of the water lubrication; a water-lubricated sticky spot is less sticky than if there were no water lubrication.

\section{Working hypothesis}

We suggest that the position of the icc-stream head is related to some threshold, down-glacier of which sufficient lubricating water and till have been gencrated to allow icc-streaming (Alley, 1990). Up-glacier of that head, steep ice-surface slopes control water flow in the ice-stream catchments, causing water flow to parallel ice flow. Along the ice stream, surface slopes are small enough that bed slopes are significant in controlling water flow.

We hypothesize that, earlier in its history, Ice Stream $\mathrm{C}$ did not reach the region of steep basal topography into which it now extends. When, perhaps by headward growth, it reached that region, basal meltwater was diverted from the catchment of Icc Stream $\mathrm{C}$ into Ice Stream B. Near the up-glacier end of the trunk, most of the subglacial water must be produced in the catchment but farther down-glacier production bencath the ice stream may be significant. Turning off the water at the up-glacier end of the trunk would have reduced lubrication on sticky spots near there, causing the icc velocity and the meltwater production there to drop. This, in turn, would have reduced lubrication on sticky spots farther down-glacier and would have stopped the ice-stream trunk in a wave propagating down-glacier.

'The velocity of down-glacier propagation would scale with the flow velocity of water in the distributed system. For a uniform film of thickness $d$, the depth-averaged flow velocity, $u$, is

$$
u=\frac{d^{2}\left|P_{\mathrm{g}}\right|}{12 \eta}
$$

where $\left|P_{\mathrm{g}}\right|$ is the maynitude of the potential gradient driving water flow and $\eta=1.8 \times 10^{-3} \mathrm{Pas}$ is the viscosity of water (Wccrtman, 1972). Taking $d=1 \mathrm{~mm}$, and $P_{\mathrm{g}}=$ $10 \mathrm{Pam}{ }^{\prime}, u \approx 15 \mathrm{kma}^{1}$, water flow would traverse the trunk length of $\approx 300 \mathrm{~km}$ in $\approx 20$ years. This is less than the uncertainty in the estimated ages of ice-stream stoppage and would appear as an instantaneous stoppage of the jcestream trunk. Various estimates of water-film thickness bascd on theory (e.g. Weerman and Birchfield, 1983; Alley and others, 1987b) yield tenths of millimeters to millimeters for the film thickness, depending on assumptions about geothermal flux, ice-stream side drag and other factors, and depending on position along the ice strcam. Kamb and Engelhardt (1991) and a personal communication from $H$. Fngelhardt and B. Kamb reported data indicating a water system with a transmissivity equal to a film averaging tenths of a millimeter thick near Upstream B, which is in the up-glacier part of a branch of Icc Stream B but which receives pirated water from the catchment of Ice Stream C.

The turn-off of the water supply would have allowed drainage of the film. That, in turn, would have lowered the water pressure in the film, decreasing the area occupied by the film and the interconnectedness of the film until water supply and transmission attained a new balance (Alley, 1989a). For the case of Ice Stream C, that balance is likcly to involve much less water transmission than beneath an active ice stream and thus much less distributed water. For a typical rift-basin heat flow, a stcady temperature profile for inactive Ice Stream C would have close to zero basal melting or freezing the calculation is the same as that for ridge BC given by Alley and Bentley (1988)). With no water supply from upglacier and with little or no basal melting and possibly even basal freeze-on, the subglacial system of Ice Stream C cannot carry much water in steady state.

The fate of the water trapped in subglacial tills is of considerable interest. A few meters of dilated till with $40 \%$ porosity Blankenship and others, 1987) might compact to $30 \%$ porosity by expelling a few tens of centimeters of water. The time-scale would depend on the ability of the distributed system between ice and till to remove water supplied to it from below. We hypothesize that the ice stream stopped because the distributed system drained and thus lost its ability to transmit much water. If the ice then regelated into the sediment (Iverson, 1993) or froze to the sediment, dewatering of till beneath the icestream trunk would require Darcian flow through the till to the grounding line. This would be a very slow process. 'The Darcian volumetric flow velocity, $u_{\mathrm{a}}$, is

$$
u_{\mathrm{a}}=\frac{-K}{\rho g} P_{\mathrm{g}}
$$

where $K$ is the hydraulic conductivity and is perhaps $10^{-6} \mathrm{~m} \mathrm{~s}^{-1}$ in a soft till (Boulton and Hindmarsh, 1987), $\rho$ is the density of water, $g$ is the acceleration of gravity and $P_{\mathrm{g}}$ is the potential gradient, and is determined primarily by the ice-surface slope along the trunk of the ice stream (along much of the trunk, the bed is nearly horizontal; Shabtaic and Bentley, 1988).

The ice-stream trunk is approximately $300 \mathrm{~km}$ long. 'To drain the water released by till dewatering (about $0.1 \mathrm{~m}$ water per meter thickness of till from just $100 \mathrm{~km}$ of that length would require that a volume of $V=10^{4} \mathrm{~m}^{3}$ flow through each meter thickness and width of till. Taking $P_{\mathrm{g}}=10 \mathrm{~Pa} \mathrm{~m}^{-1}$, the time to drain the water is $V / u_{\mathrm{tl}}=3 \times 10^{5}$ a. Clearly, drainage can be faster if a limited ice-contact water system remains, or if drainage through sub-till sediments is allowed, and we would expect these. However, retaining dilated tills for $10^{2}$ a is certainly possible.

The headward extension of the ice streams postulated here may be an expected development. $\Lambda t$ the end of the last ice age, the ice sheet experienced a large surface warming, which now should be causing basal warming 
and increased basal melting (Whillans, 1978). Increased basal melting would allow the headward extension of ice streams in at least some models (e.g. Alley, 1990). If so, then the region of steep bedrock topography under the heads of Ice Streams B and C would at one time have been under steep surface slopes, but the surface slopes would have become flatter over time, eventually diverting the water flow and stopping Ice Stream C.

The rapid headward extension of Ice Stream B observed by Shabtaie and others (1988) may be related to this expected slow headward growth of the ice streams. It also may have been accelerated significantly by additional lubricating water obtained from Ice Stream C.

\section{PROBLEMS AND TESTS}

We see a few problems with this hypothesis. One is that we have not quantified it - we do not have a numerical model running that produces the stoppage of Ice Stream $C$ as a natural consequence. 'That might be a good test of our hypothesis, but we do not anticipate it any time soon. There now is so much freedom in terms of till-flow laws, sticky-spot character, water-system geometry and so on, that we suspect that we can develop a model that either would or would not stop Ice Stream $\mathrm{C}$ for the scenario outlined here. We thus have not attempted that exercise, although it might be interesting to find out just how wide the range of possible behavior is.

Given the rapid changes over time observed in icesurface elevations elsewhere on the Siple Coast, a detailed modern determination of water-flow divides does not necessarily tell us where they were 130 years ago when the trunk of Ice Stream C stopped. For example, we postulate that the limb remains active while the trunk has stopped. The ice input from the limb thus would be piling up near where the limb and trunk mect. Supposc the limb is $1 \mathrm{~km}$ thick and has flowed at $100 \mathrm{ma}^{1}$ for 100 years after the trunk stopped. Suppose, further, that the limb-trunk junction has thickened by $100 \mathrm{~m}$ in this time, and the thickening decreases linearly and symmetrically away from the junction up-glacicr and down-glacier. Mass continuity would require the thickening to extend $100 \mathrm{~km}$ along-flow in each direction, with ice-surface slope having decreased up-glacier of the junction and increased downglacier of the junction.

It is intriguing that the $100 \mathrm{~km}$ immediately up-glacier of the junction today has a flatter surface slope than the $100 \mathrm{~km}$ down-glacier (Shabtaie and others, 1988; Retzlaff and others, 1993), whereas surface slope generally decreases down-glacier on the other ice streams (Shabtaie and others, 1988). However, if we allow such large thickness changes, and the possibility that icc-surface slopc changed transverse to the ice stream as well as along it, we cannot reconstruct water-flow paths from 100 years ago with great confidence.

Our greatest difficulty is that we cannot provide any unequivocal test of our hypothesis. Some of our assumptions can be tested (till discontinuity under the trunk of Ice Stream $C$ and continued activity of the limb) but correctness of these assumptions would not cstablish correctness of our model. It would be interesting to see whether micro-earthquake activity is lower in the limb than in the trunk - in our model, water lubrication of sticky spots should minimize quakes up-glacier but not down-glacier.

We postulate that the wave of stagnation of the ice stream propagated down-glacier following water piracy. Retzlaff and Bentley (1993) postulated that the wave of stagnation propagated up-glacier as the subglacial water film collapsed to channels, starting at the grounding line where the film was thickest. Further short-pulse radar studies of the burial depth of marginal crevasses on the trunk of Ice Stream C, of the type already reported by Retzlaff and Bentley (1993), might provide the clearest test of these models if the short duration of the wave of stagnation could be resolved.

An informal reviewer suggested that, because water flow in Figurc 1 passes beneath ridge $\mathrm{BC}$, between Ice Streams $B$ and $C$, but ridge $B C$ is not an ice stream, we have a difficulty with our model. We do not consider this to be a serious problem for three reasons:

(i) Water flow is a necessary but not sufficient condition for ice streaming in our model, which also invokes till for much of the lubrication. It may be that conditions are not right for till gencration in that part of ridge $\mathrm{BC}$ receiving water from the Ice Stream $\mathrm{C}$ catchment, or that there is a time lag for generating enough till to lubricate fast flow.

(ii) As shown in Figure 1, water is funneled into the active regions of Ice Stream $B$ but there is no funneling of the water crossing ridge $\mathrm{BC}$. Perhaps not enough water reaches ridge $\mathrm{BC}$ to provide sufficient lubrication for streaming flow.

(iii) The maps and calculations of Shabtaie and others (1988) suggest, although they do not prove, that Ice Stream B is growing at the expense of ridge $B C$ in that region of ridge $\mathrm{BC}$ receiving water diverted from Icc Stream C: If so, then perhaps the effects of the water piracy are just now being manifested.

Although all of these are clearly hypothetical, they also are possible.

\section{SUMMARY}

Data reported recently show that the trunk of Ice Stream C stopped almost synchronously about 130 years ago. The limb extending up-glacicr stopped more recently or is still active. The trunk of the ice stream has a well-lubricated bed in most places but with local stress concentrations suggesting sticky spots. The lubrication is probably supplied by a soft till layer. Near where the limb meets the trunk, the ice stream has very gentle surface slopes overlying steep bed slopes, and a new map of modern hydrologic potential indicates that meltwater from the catchment and limb of Ice Stream $C$ drains into Ice Stream B rather than into Ice Stream C.

We hypothesize that the ice streams have been extending slowly into the inland ice in response to increased basal melting there caused by Holocene warmth. When the nearly flat ice-stream surfaces reached the steep basal topography now bencath the limb/trunk junction, water piracy occurred with the 
water from the Ice Stream C catchment diverted to Ice Stream B. This caused enhanced headward growth of Ice Stream B. This water diversion reduced lubrication on sticky spots beneath Ice Stream C where till was thin or absent, causing their drag on ice flow to increase and the ice stream to stop. As the distributcd water system drained, the soft, dilated till around the sticky spots lost a ready conduit for water released during compaction, so dewatering has been slow and the till remains soft.

If our hypothesis is correct, then the limb of Ice Stream $C$ is still active, the till bencath Ice Stream C should be discontinuous or at least variable in thickness, and the ice stream should have stopped in a wave propagating down-glacier from the region of the limb/ trunk junction.

\section{ACKNOWLEDGEMENTS}

We thank the U.S. National Science Foundation and the D. and 1. Packard Foundation for financial support, and I. Whillans, S. Shabtaie and other members of the West Antarctic Ice Sheet Project for suggestions, discussions and data access. This is contribution No. 540 of the Geophysical and Polar Research Center, University of Wisconsin-Madison.

\section{REFERENCES}

Alley, R. B. 1989a. Water-pressure coupling of sliding and bed deformation: I. Water system. 7. Glaciol, 35(119), 108-118.

Hlley, R.B. 1989b. Water-pressure coupling of sliding and bed deformation: II. Velocity-depth profiles. F. Glaciol., 35(119), 119-129.

they, R. B. 1990. Multiple steady states in icc-water-till systems. Ann. Giaciol.. 14, 15 .

Hley, R. B. 1993. In scarch of ice-stream sticky spots. $\mathcal{f}$. Glaciol., 39 : 133$), 447-454$

Mlev, R. B. and C. R. Bentley, 1988. Ice-core analysis on the Siple Coast of West Antarctica. Amn. Glaciol., 11, 17.

Aley, R. B. and I. M. Whillans. 1991. Changes in the West Antarctic ice sheet. Science, 254 5034! 959-963.

Allcy, R. B., D. D. Blankenship, C. R. Bentley and S. T. Rooney. 1987a. Continuous till deformation beneath ice sheets. Intemational Arsociation of Hydrological Sciences (Symposium at Vancouver 1987- The Physical Basis of Ice Sheet Modelling). 8191.

Alley, R. B., D. D. Blankenship, C. R. Bentley and S. T. Rooney. 1987 b. Till beneath Icc Strcam B. 3. Till deformation: cvidence and implications. ff. Geoplys. Res., 92(B9), 8921-8929.

Anandakrishnan, S. and R. B. Alley. 1994. Ice Stream C, Antarctica, sticky spots detected by micro-carthquake monitoring. Ann. Glaciol., 20 (see paper in this volume)

Anandakrishnan, S. and C.R. Bentley, 1993. Micro-earthquakes beneath Ice Streams B and C, West Antaretica: observations and implications. 7. Glaciol., 39(133), 455-462.

Itre, S. R. and C. R. Bentley. 1990. Laterally varying basal conditions under Ise Stream C, Antaretica. [Abstract.] EOS, 71(43), 1303.

Atre. S. R. and C. R. Bentley 1993. Laterally varying basal conditions beneath Ice Streams B and C. West Antarctica. 7. Glaciol, 39 133), $507-514$.

Bindschadler, R. A. 1993. Siple Coast Project research of Cirary Ice Rise and the mouths of Ice Streams $B$ and C, West Antarctica: review and new perspectives. J. Glaciol., 39(133), 538-552

Bindschadlcr, R. A., S. N. Stephenson, D. R. MacAyeal and S. Shabtaie. 1987. Ice dinamics at the mouth of Icc Stream B. Antarctica. 7 . Geophrs. Res, 92(B9), 8885-8894.

Bindschadler, R. A., E. P. Roberts and D. R. MacAyeal. 1989. Disuribution of net mass balance in the vicinity of Crary Ice Rise, Antarctica. 7. Glaciol, 35 121$), 370-377$

Bindschadler, R., P. L. Vornberger and S. Shabtaie. 1993. The detailed net mass balance of the ice plain on Ice Stream B: a geographic information sustem approach. 7. Glaciol., 39(133), 471-482.
Blankenship, D. D., C. R. Bentley, S. T. Rooney and R. B. Alley. 1987. Till beneath Ice Stream B. 1. Properties derived from seismic travel times. 7. Geophys. Res., 92(B9), 8903-8911.

Boulton, G.S. 1976. The origin of glacially fluted surfaces-observations and theory. 7. Glaciol, 17(76), 287-309

Boulton, G. S. and R. C.A. Hindmarsh. 1987. Sediment deformation beneath glaciers: rheology and geological consequences. 7. Geophys. Res., 92(B9), 9059-9082.

Boulton, G. S. and A. S. Jones. 1979. Stability of temperate ice caps and ice sheets resting on beds of deformable sediment. J. Glaciol., 24 (90), $29-43$

Brune, J. N. 1970. Tectonic stress and the spectra of seismic shear waves from earthquakes. 7. Geophys. Res., 75 26), 4997-5009.

Das, S. 1992. Reactivation of an oceanic fracture by the Maquaric Ridgc earthquake of 1989. Nature, 3576374), 150-153.

Hill. D. P. and 30 others. 1993. Seismicity remotely triggered by the magnitude 7.3 Landers, California carthquake. Science, 260(5114), $1617-1623$.

Iverson, N. R. 1993. Regelation of ice through debris at glacier beds: implications for sediment transport. Geology, 21 6), 559562 .

Jacobel, R. W., A. M. Gades, D. L. Gottschling, S. M. Hodge and D. I. Wright. 1993. Interpretation of radar-detected internal layer folding in West Antarctic ice streams. 7. Glaciol., 39(133). 528-537.

Kamb, B. 1987. Glacier surge mechanism based on linked cavity configuration of the basal water conduit system. $\tilde{J}$. Geophys. Res. 92(B9), 9083-9100

Kamb, B. 1991. Rheological nonlinearity and flow instability in the deforming bed mochanism of icc strcam motion. 7. Geophys. Rex. 96(B10), 16,585-16,595.

Kamb, B. and H. Engelhardt. 1991. Antarctic Ice Stream B: conditions controlling its motions and interactions with the climate system. International Association of Hydrological Sciences Publication 208 'Symposium at St. Petersburg 1990-Glaciers-Ocean-Atmosphere Interactions), 145154 .

Kamb, B. and 7 others. 1985. Glacier surge mechanism: 1982-1983 surge of Variegated Glacier, Alaska. Science, 227(4686), 469-479.

MacAyeal. D. R. 1992. The basal stress distribution of Ice Stream E, Antarcica, inferred by control methods. 7. Geophys. Res., 97(BI), $595-603$.

MacAyeal, D. R., R.A. Bindschadler, S. Shabtaie, S, Stephenson and C. R. Bentlev. 1987. Force, mass and energy budgets of the Crary Ice Risc complex, Antarctica. F. Glaciol., 33(114), 218-230.

MacAyeal, D. R., R.A. Bindschadler, S. Shabtaie, S. Stephemson and C. R. Bentley. 1989. Correction to: Force, mass and energy budgets of the Crary Icc Risc complex, Antarctica. 7. Glaciol., 35 119), 151-152

Paterson, W.S. B. 1981. The physics of glaciers. Second edition. Oxford, etc., Pergamon Press.

Radok. U., D. Jenssen and B. MrInnes. 1987. On the surging potentiat of polar ice streams. Anlarclic surges - a clear and present danger? Washington, DC, U.S. Department of Energy. (DOE/ER/60197-H 1.)

Retzlaff, R. and C. R. Bentley. 1990. Buried surface crevasses in Ice Stream $C$ idetected by short-pulse radar sounding. [Abstract.」 EOS 71:43). 1303

Retzlaff, R. and C. R. Bentley. 1993. Timing of stagnation of Ice Stream C, West Antarctica, from short-pulse radar studies of buried surface crevasses. F. Glaciol., 39(133), 553-561.

Retzlaff, R., N. Lord and C. R. Bentley. 1993. Airborne-radar studies: Ice Streams A, B and C. West Antarctica. 7. Glaciol, 39 133, 495-506.

Rooncy, S. T., D. D. Blankenship, R. B. Alley and C. R. Bentley. 1987. Till beneath Ice Stream B. 2. Structure and continuity. $f$. Geophys. Res., 92(B9), 8913-8920.

Rose, K. F. 1979. Characteristics of ice flow in Marie Byrd Land, Antarctica. J. Glaciol., 24/90), 63-74.

Shabtaie, S. and C. R. Bentley. 1988. Ice-thickness map of the West Antarctic icc strcams by radar sounding. Ann. Glaciol., 11, 126-136.

Shabtaic, S., I. M. Whillans and C. R. Bentley. 1987. The morphology of Ice Streams A, B, and C, West Antarctica, and their emvirons. 7 . Geophys. Res., 92(B9), 8865.8883

Shabtaic, S., C. R. Bentlcy, R. A. Bindschadler and D. R. MacAyeal. 1988. Mass-balance studies of Ice Streams A, B, and C, West Antarctica, and possible surging behavior of Ice Stream B. Ann. Glaciol., 11, 137-149.

Stephenson, S. N. and R.A. Bindschadler. 1988. Observed velocity fluctuations on a major Antarctic ice stream. Nature, 334(6184, 695-697.

Thomas, R.H., S. N. Stephenson, R. A. Bindschadler, S. Shabtaie and G. R. Bentley. 1988. Thinning and grounding-line retreat on Ross Ice Shelf, Antarctica. Ann. Glaciol., 11, 165-172.

Walder, J.S. 1982. Stability of sheet flow of water beneath temperate glaciers and implications for glacier surging. f. Glaciol., 28(99), 273293. 
Walder, J. S. and A. Fowler. 1991. Channelized subglacial drainagre over a deformable bed. 7. Glaciol., 40 $134 ;, 3-1.5$.

Weertman, J. 1972. General theory of water flow at the base of a glacien or icc sheet. Rew Geopless. Space Phss, 10 1), 287-333.

Wecrtman, J. and G. E. Birchfield. 1983. Stability of sheet water flow under a glacier. 7. Criaciot., 29: 103;, 374-382.

Whillans, I. M. 1978. Inland isc sheet thinning due to Holocrno warmth, Science, $201(4360), 1014 \cdot 1016$.

Whillans, I. M. and R. A. Bindschadler. 1988. Mass balance of Ice Stream B, West Antarctica. Ann. Glaciol., 11, 187-193.

Whillans, I. M. and C.J. Van der Veen. 1993. New and improved detrminations of velocity of Ice Streams B and C, West Antarctica. J. (ilaciol, 39 (133), 483-490.
Whillans, I. M.. J. Bolzan and S. Shabtaic. 1987. Velocity of Ice Streams B and (i, Antarctica. 7. Geophys. Res., 92(B9), 8895-8902.

Myss, M. and J. N. Brume. 1968. Seismic moment, stress, and source dimensions for carthcyuakes in the California Nerada region. ff. Geophys. Res., 7314;, $4681 \cdot 4694$.

The accuracy of references in the text and in this list is the responsibility of the authors, to whom queries should be addressed. 